\title{
THE SINHALESE CONTRIBUTION TO ESTATE LABOUR IN CEYLON, 1881-1891
}

BY

\author{
ROLAND WENZLHUEMER*
}

\section{Abstract}

It has become a firmly established belief among economic and labour historians that Sri Lanka's plantation industry rested almost exclusively on imported Tamil labour during the 19th century. Although strong evidence countering this "dualistic" viewpoint has been produced since the late 1970s - especially by Éric Meyer-, the contribution of the local Sinhalese peasantry to estate wage labour remains underestimated or, indeed, largely ignored. This article strives to support Meyer's point by bringing together old and new evidence illustrating the at times substantial Sinhalese participation in plantation wage labour.

C'est une croyance bien établie parmi les historiens économiques et du travail que l'industrie de la plantation du Sri Lanka reposait presque exclusivement sur le travail de la main-d'čuvre tamoule pendant le 19e siècle. Bien que des indications fortes contre cette perspective "dualiste" aient été produites depuis les années 70-particulièrement par Éric Meyer-, la contribution de la paysannerie locale cinghalaise au travail salarié dans les plantations reste sous-estimée, ou en grande partie ignorée. Cet article tâche de soutenir l'opinion de Meyer en rassemblant des indications vieilles et nouvelles illustrant la participation cinghalaise parfois substantielle au travail salarié dans les plantations.

Keywords: Sri Lanka, Labour History, Sinhalese Labour, Migrant Labour, Plantation Wage Labour

\section{INTRODUCTION}

Historical works on the composition and social structure of the labour force on 19th-century Ceylonese export crop plantations have long propagated the myth that this workforce consisted almost exclusively of "imported" Tamil labourers. Éric Meyer has challenged this notion more than twenty-five years ago in his work on Sinhalese estate labour in Ceylon. ${ }^{1}$ Meyer produced first

\footnotetext{
* Roland Wenzlhuemer, Centre for British Studies, Humboldt University, Berlin, Germany, roland.wenzlhuemer@staff.hu-berlin.de

${ }^{1}$ É. Meyer, "Between Village and Plantation. Sinhalese Estate Labour in British Ceylon," in Asie du Sud Traditions et Changements. VIth European conference on Modern South Asian 
evidence illustrating large-scale Sinhalese participation in plantation labour since, at least, the late 1870s. However, Meyer's evidence failed to convince labour historians with a more "dualistic" approach and did not provoke further research on the subject. In his 2001 publication on the "Plantation Tamils of Ceylon" Patrick Peebles even questioned the-hitherto assumed-significant Sinhalese participation in estate labour during the earliest phase of coffee plantation history in Sri Lanka in the 1820s and 1830s. ${ }^{2}$ Peebles also doubts the "cyclic" nature of Tamil labour migration to Ceylon during coffee days and thus left little room for a Sinhalese contribution to estate labour. The counter evidence produced by Éric Meyer twenty years earlier received little attention in the subsequent discussion of 19th century estate labour. Therefore, this article strives to bring together more such evidence-produced before and after Meyer's paper-in order to strengthen Meyer's notion of the significant role of the local Sinhalese in plantation labour. The article offers a statistical approach to the matter and tries to provide an outlook for further research.

\section{TAMIL AND SinHALESE ESTATE LABOUR}

Early in the 19th century the densely populated Indian subcontinent became the major labour supplier for the rest of the colonised world. In the overpopulated regions of the Madras Presidency landlessness was widespread and droughts and famines occurred frequently. The number of landless agricultural labourers in the South Indian districts-already about 10 to $15 \%$ of the total population at the beginning of the 19th century-further increased throughout the century. ${ }^{3}$ This has mainly been attributed to the "disintegration of the Indian village handicraft industries consequent on the flooding of the Indian market with cheaper British-manufactured articles." ${ }^{4}$ Village artisans could not compete with the British producers and had to make a living as agricultural wage labourers. While many resorted to indentured labour in distant parts of the world, others started to respond to the emerging "job opportunities" in regions less far from their homeland-for instance in the Kandyan highlands of Sri Lanka. In the early decades of South Indian labour migration to Ceylon, i.e. in the $1830 \mathrm{~s}$ and 1840s, word-of-mouth induced a steadily growing number of Tamil labourers

Studies, Sevres. 8-13 Juillet 1978. (Colloques internationaux du Centre national de la recherche scientifique) (Paris: CNRS, 1978), 1-10.

${ }^{2}$ P. Peebles, The Plantation Tamils of Ceylon (London; New York: Leicester University Press, 2001).

3 D. Wesumperuma, Indian Immigrant Plantation Workers in Sri Lanka. A Historical Perspective 1880-1910 (Kelaniya: Sri Lanka Foundation Institute, 1986), 15.

4 Wesumperuma, Indian Immigrant Plantation Workers, 16. 
to undertake the strenuous journey across the Paumben Strait and up into the highlands. But with the area under coffee cultivation expanding and labour demands rising rapidly, Indian labour immigration became more organised to secure the presence of a steady and reliable workforce.

Regarding the Sinhalese contribution to regular estate wage labour during the early years of coffee cultivation, little has been researched and written on thisand when we find clear statements on that topic, scholarly opinions diverge. While it seems to be a widespread view among economic historians of 19thcentury Ceylon that the first coffee planters of the 1820s and 1830s employed Sinhalese wage labour as well, relied largely on Sinhalese labour or at least desperately tried to recruit local Sinhalese labour, this view has recently been challenged by Patrick Peebles in "The Plantation Tamils of Ceylon." Peebles holds that there was only scarce evidence pointing to planters' attempts at trying to hire a local Sinhalese plantation labour force. Most references regarding Sinhalese villagers employed on the estates would only "praise their skill at felling jungle." With only rare references to the composition of the early coffee labour force, it remains difficult to fix the Sinhalese contribution to estate wage labour in the 1820 s and 1830s. However, as cited by Peebles, ${ }^{6}$ Boyd refers to Sinhalese labourers working under Sinhalese foremen on plantations in the year 1838. This generally supports the notion that as soon as in the 1820 s and 1830 s a certain number of Sinhalese villagers had taken to estate wage labour beyond mere contract work-presumably mostly those who lived in the vicinity of the plantations and were able to return to their villages every evening. ${ }^{7}$ However, it is reasonable to suggest that their number remained comparatively small when we consider the frequent ill-treatment of the workers by estate superintendents ${ }^{8}$ and, above all, the as yet missing economic pressure.

During the early 19 th century most indigenous peasants managed to make a comparatively good living from their paddy fields, small coffee gardens and other garden crops-supplemented with produce from shifting cultivation (chena). Pressure on agricultural land was still comparatively low and the peasantry's tax burden was light and mostly payable in kind. Hence, only a small percentage of the indigenous rural population of mid- and upcountry Ceylon felt

5 Peebles, Plantation Tamils, 30.

${ }^{6}$ Peebles, Plantation Tamils, 30.

7 See F. Heidemann, Kanganies in Sri Lanka and Malaysia. Tamil Recruiter-cum-Foreman as a Sociological Category in the Nineteenth and Twentieth Century (Munich: Anacon Verlag, 1992), 11.

${ }^{8}$ M. W. Roberts, "Indian Estate Labour in Ceylon during the Coffee Period (1830-1880)Part I," The Indian Economic and Social History Review 3 (1966): 1. 
an economic pressure high enough to push them into plantation wage labouran occupation not held in high esteem by the villagers. As plantation labour demands could not be satisfied locally, economic pull factors cooperated with the push factors in Southern India and induced a steadily growing number of Tamil labourers to migrate to the Kandyan coffee estates.

\section{THE "DuAlistic” MODEL}

The import of foreign labour to the plantations co-founded the myth of the existence of a so-called "dualistic" economic model in 19th-century Sri Lanka. The "dualistic" approach propagates the existence of two absolutely separated economic sectors with different modes of production-the allegedly modern plantation sector and the traditional, i.e. "backward," subsistence sector. From a "dualistic" viewpoint, the plantation sector lives exclusively on foreign capital, employs a foreign workforce and produces for a foreign market. It, hence, exists completely aloof of the indigenous subsistence agriculture. In his extremely influential 1966 study of Ceylon's economy Donald R. Snodgrass firmly established this "dualistic" notion among economists and historians alike. Snodgrass pointed out:

In structure, the economy [of 19th-century Sri Lanka] was a veritable model of what might be called a dualistic export economy. [...] The dualism of the economy was very nearly perfect. The estate and peasant economies touched at relatively few points. ${ }^{9}$

Snodgrass' simple model of a "dualistic" economy-featuring a strong and modern plantation sector and an allegedly backward subsistence sector-proved to be easy to handle and experienced widespread reception and acceptance. Although writers like Gamini Corea ${ }^{10}$ and Éric Meyer ${ }^{11}$ refuted Snodgrass' approach, the "dualistic" model and its implications reverberate in much of what has been written on 19th-century Sri Lankan agricultural economy until today. It has been largely ignored that soon after the introduction of plantations as agricultural production units to the central highlands several points of contact between the export and the subsistence sector emerged.

9 D. R. Snodgrass, Ceylon. An Export Economy in Transition (Homewood, Ill: Richard D. Irwin, 1966), 56-7.

${ }^{10}$ G. Corea, The Instability of an Export Economy (Colombo: Marga Institute, 1975).

11 É. Meyer, “'Enclave' Plantations, 'Hemmed-In' Villages and Dualistic Representations in Colonial Ceylon," in Plantations, Peasants and Proletarians in Colonial Asia. Special Issue of Journal of Peasant Studies, Vol. 19, No. 3+4, ed. E. V. Daniel, H. Bernstein, and T. Brass (London: Cass, 1992). 


\section{ENTER THE Plantation ECONOMY}

In the 1840 s traditional subsistence agriculture in Sri Lanka witnessed the emergence of an alternative-potentially rival-mode of agricultural production: the plantation system. Coffee cultivation rose to become the main-and solebackbone of the small island's export economy. After four decades of unchallenged expansion, coffee monoculture found a sudden and for many unexpected end in the early 1880s. The so-called Coffee Leaf Disease completely wiped out coffee cultivation in only a few years and left the Crown Colony's economy crippled. Monoculture had facilitated the spread of the disease, and it had maximised its impact on the island's economy. The economic depression triggered by the ruin of coffee cultivation is an almost prototypical example for the hazards connected to agrarian monoculture.

After several years of severe economic depression the planters started to invest their remaining capital into tea cultivation, which proved to be highly profitable and began to expand at breakneck speed. In 1900, Ceylon exported around 150 million lbs. of tea with an export value of almost 54 million Indian Rupees. This accounted for $56,6 \%$ of the total export value of that year. ${ }^{12}$ Again, the Ceylonese economy depended almost exclusively on the production and export of one crop-a crop that had been almost unknown in the island only twenty years earlier. In 1880, Ceylon had exported only $162.576 \mathrm{lbs}$. of tea accounting for 150.641 Rupees or $0,3 \%$ of the total export value. ${ }^{13}$ In that year, coffee had still accounted for $62,9 \%$ of the total export value. ${ }^{14}$ Within less than ten years hundreds of thousands of acres under coffee had been transformed into thriving tea plantations. The high initial capital outlay started to pay, economies-of-scale developed and the area under tea cultivation expanded quickly.

\section{INTERSECTORIAL CONTACTS}

Soon after the introduction of plantation agriculture to the island, a number of spheres of contact between the new and the indigenous sector emerged. Gamini Corea named at least four such touching points: ${ }^{15}$ First, the expansion of coffee cultivation (and later that of tea) drastically increased the pressure on

Ceylon Statistical Blue Book 1900.

3 Ceylon Statistical Blue Book 1880.

${ }^{4}$ Ceylon Statistical Blue Book 1880.

15 Corea, The Instability of an Export Economy, 67-8. 
land in the Kandyan highlands. ${ }^{16}$ Second, a good part of the Kandyan peasantry participated actively in the cultivation of coffee and derived a certain cash income from their coffee gardens. Third, a significant number of Sinhalese villagers worked on the plantations or in road and railway construction. In the early decades the Sinhalese contribution to estate or construction labour was primarily contract work for a task or period of time. But we will soon see that in the late 1880s many Sinhalese villagers were pushed into regular plantation labouran alleged Tamil domain. Fourth, the improvement of the island's infrastructure gradually linked up many of the more remote regions with the large towns of Colombo, Kandy and Galle, thus furthering the monetisation of the villages and opening up the plantations as markets for the villages' garden produce.

Éric Meyer adds a fifth linkage between the plantations and the villages. While the estates became more and more a market for village produce, the villages — with their permanent paddy shortages - at the same time became a market for the excess rice of the Tamil coolies. ${ }^{17}$ The plantation labourers bartered their excess rice for other supplementary foodstuffs or-mainly-for arrack. Thus, the imported Indian rice found its way into the Sinhalese villages. As a sixth sphere of contact between the plantation and the subsistence sector we might add the ecological effects of the expansion of the plantation industry. James Webb has discussed these in some detail in a recent publication. ${ }^{18}$ From these observations it becomes clear that the fortunes of the planters and those of the indigenous agriculturists were closely interlinked right from the introduction of plantation agriculture.

\section{Composition of Estate Labour In LATE 19TH-CENTURy CEYlon}

The first coffee plantations in Sri Lanka in the 1820s and 1830s already employed Tamil immigrant labourers from South India. However, Sinhalese labourers recruited from the neighbouring villages contributed substantially to the running of the plantation by clearing the jungle (or other contract work) but also by taking up estate labour on a regular basis (i.e. picking and processing of coffee berries,

16 The government issued several notorious ordinances in order to secure European land titles in the region. The Crown Lands Encroachment Ordinance of 1840 "enacted that all Forest, Waste, Unoccupied and uncultivated Lands shall be presumed to be the property of the Crown" and laid the burden of proving claims to such land solely on the claimant.

CO 56/1, Ceylon Acts 1835-1840.

17 Meyer, “'Enclave' Plantations, 'Hemmed-In' Villages,” 206.

18 J. L. A. Webb, Tropical Pioneers. Human Agency and Ecological Change in the Highlands of Sri Lanka, 1800-1900 (Athens: Ohio University Press, 2002), 87-8. 
planting, estate maintenance). The labour demands of the few existing plantations were low enough to be satisfied with only a small number of Tamil immigrant workers. But the rapid expansion of plantation agriculture in the 1840s soon created an ever-increasing labour demand. The Sinhalese did not respond to these pull factors in numbers large enough — but the impoverished Tamil villagers across the Paumben Strait in South India did. The combination of economic push and pull factors on both sides of the Strait gained momentum and began to attract the first labour immigrants to the plantations of Ceylon. In the early days of Tamil immigration, i.e. in the 1820s and 1830s, word-of-mouth among the Tamil villagers generally sufficed to satisfy the labour requirements of the Ceylonese plantations. But in later years, rising labour demands led to the semi-organisation of labour migration. Structures emerged and the system proved to be a financial and organisational success for the planting community. From the 1850s onwards, plantation labour in Sri Lanka seemed to be an almost exclusively Tamil domain-with the local Sinhalese allegedly too well-off and well-fed to resort to wage labour at all. ${ }^{19}$

Éric Meyer challenged this notion more than twenty-five years ago in his work on Sinhalese estate labour in Ceylon. His "main argument is that the role played by Sinhalese labour has always been underestimated, owing to the paucity of historical evidence, and that at least in precise areas, at definite periods, it was necessary to the economic balance of the plantation as well as to that of the village." 20 Meyer produces first evidence to underline his argument illustrating large-scale Sinhalese participation in plantation labour since, at least, the late 1870 s. A statistically backed estimate on plantation labour requirements and Sinhalese participation provided in the present work will support Meyer's suggestion that the "extensive land sales under the Paddy Tax and the evictions that followed in the Badulla and Nuwara Eliya districts in the 1880's [. . .] may have some bearing on the notable extent of Sinhalese labour in an area where the peasantry was nearest the subsistence level."21

It remains undisputed that from the coffee boom years onwards Tamil immigrants constituted the largest number of the plantation labour force. However,

19 Patrick Peebles has recently pointed out that the longstanding "colonial myth" of the Sinhalese peasants' reluctance to take up wage labour has mainly been a British construction to justify the "import" of Tamil labour. Although this is certainly true, missing economic incentives and-not to forget - the labour requirements of their own holdings have long kept the Sinhalese from partaking in regular plantation wage labour in any substantial numbers.

Peebles, Plantation Tamils, 30.

${ }^{20}$ Meyer, "Sinhalese Estate Labour," 1.

${ }^{21}$ Meyer, "Sinhalese Estate Labour," 6. 
in smaller numbers the Sinhalese have constantly participated in plantation labour throughout the 19th century. These labourers mostly represent the part of the Sinhalese peasantry that enjoyed less access to fertile land or was heavily indebted. During the coffee days this Sinhalese contribution to estate labour remained relatively low. In 1881, the year of the first official and fairly reliable population census, only $4,07 \%$ of the resident male workers were Sinhalese. But taking a look at the corresponding figures for the year 1891 we find that this percentage had risen to $8,46 \% .^{22}$ Considering the reluctance that the peasants must have felt to leave their homes and villages behind and take up permanent residence on an estate, we can safely assume that only those with little other choice have done so. Hence, many peasants in that time must have experienced enormous economic pressure that pushed them into residing and working on the foreign-owned estates. It is equally safe to further assume that even more Sinhalese resorted to commuting between their home villages and the estates and took up non-resident wage labour.

Unfortunately, the statistical material left behind by the British administrators-generally fairly reliable but naturally also subject to a certain bias-does not contain any data on the number of Sinhalese villagers involved in plantation wage labour. The censuses only give the numbers of resident plantation labourers, but in the Administration Report of 1887 the Director of the Royal Botanical Gardens at Peradeniya, Henry Trimen, states:

It is with unalloyed satisfaction that all who wish well to the Sinhalese must see that a real beginning has been made in inducing them to work as daily labourers on the teaestates. Managers are gladly employing this Sinhalese labour where they can obtain it, and in some cases are paying something above the usual rate of cooly wages as an inducement; the work is light, easy, and constant throughout the year. In the general interest of the country it is greatly to be hoped that everything will be done by those who have authority over, and influence with, the impoverished villagers to help them to overcome their prejudices and accept this regular work now offered to them. ${ }^{23}$

Similarly, the planter Frederick Lewis in his autobiography describes his plantation workforce as composed mainly of Sinhalese villagers and points out the steady increase of Sinhalese plantation labour throughout the island. ${ }^{24}$ Although statements in the Administration Report as well as the memoirs of a planter might show a distorted picture of coolie reality, these descriptions together with

22 Report on the Census of 1891, p. 41.

${ }_{23}$ CO 57/101, Administration Report 1887, Royal Botanical Gardens, p. 12D.

${ }^{24}$ F. Lewis, Sixty-Four Years in Ceylon (Colombo: The Colombo Apothecaries Company, 1926) 191-2. 
census figures on resident Sinhalese estate labour indicate a marked increase of the Sinhalese villagers working on the estates between 1881 and 1891 .

Although the population censuses remain silent on this issue, the annual figures on plantation acreage collected in the Blue Books further support the notion that impoverished Sinhalese villagers resorted to regular estate labour in high numbers during periods of economic duress. From the data available to me at the present moment, it is not possible to furnish an estimate of the number of non-resident Sinhalese employed on the plantations between 1881 and 1891 . Nevertheless, the few figures we have at our disposal do hint at a marked influx of local labour to the estates. ${ }^{25}$

Contemporary estimates speak of a requirement of 3 to 4 labourers per acre for the cultivation of tea, while coffee cultivation required only one coolie per acre. This estimate is definitely exaggerated, but a more conservative and more reliable estimate puts the requirements for tea at 2 labourers per acre and for coffee at $3 / 4$ of a labourer per acre. ${ }^{26}$ Consulting the acreage figures of the 1881 Statistical Blue Book, we learn that still about 360.000 acres were under coffee in that year. ${ }^{27}$ Making allowances for peasant coffee (approximately $15 \%$ of the acreage) and taking into account the low coffee yields (and lower labour requirements) we arrive at a total labour requirement for coffee cultivation of around 150.000 labourers. Following similar lines of thought and the acreage figures for tea (between $14.350^{28}$ and $22.000^{29}$ acres with approximately 2.720 acres in full bearing ${ }^{30}$ ), cinchona and cacao (together about 50.000 acres) $^{31}$ as given in the official statistics, the total labour force required on the plantations

25 The following calculation has been exercised in full detail in the paper I presented at the 17th ECMSAS, September 2002, Heidelberg. The statistical material and methods employed in the calculation have evoked discussions and criticism among colleagues ever since. Hence, I explicitly point out again that this calculation does not mean to derive exact labour requirements (which is, indeed, impossible with the data employed), but solely strives to illustrate the marked increase in Sinhalese estate labour between 1881 and 1891 by showing a trend in labour requirements. R. Wenzlhuemer, "Reconsidering the Sinhalese Contribution to Estate Labour in late 19th Century Ceylon," Paper presented at the 17th European Conference on Modern South Asian Studies in Heidelberg, September 9-14, 2002.

${ }^{26}$ L. A. Wickremeratne, "The Establishment of the Tea Industry in Ceylon. The First Phase, c. 1870 to c. 1900," Ceylon Journal of Historical and Social Studies (new series) 2 (1972): 142.

27 Ceylon Statistical Blue Book 1881.

28 Ceylon Statistical Blue Book 1881.

29 Ferguson's Ceylon Handbook and Directory, 1913-14.

${ }^{30}$ Ferguson's Ceylon Handbook and Directory, 1913-14.

31 Derived from S. Rajaratnam, "The Growth of Plantation Agriculture in Ceylon, 18861931," Ceylon Journal of Historical and Social Studies 4 (1961): 3-4. 
in the year 1881 accounts to about 200.000 workers. The census for the year 1881 puts the number of people living (and therefore working) on the Ceylonese plantations at $206.500^{32}$-including labourers as well as managing and supervising staff. Although we take into account that the labour and acreage estimates employed in this calculation were chosen from the lower side of the possible spectrum, we arrive at too low a result. Hence, it is even more striking that the same calculation based on the respective figures for the year 1891 arrives at an estimated labour requirement of over 450.000 workers, ${ }^{33}$ while the 1891 census gives only 262.000 persons as resident on the estates. ${ }^{34}$ A provincewise look at the figures for 1891 further supports these findings. With 168.000 acres under tea and still 44.000 acres under coffee in the Central Province in that year, ${ }^{35}$ only 183.000 resident estate labourers-according to the findings of the Population Census ${ }^{36}$ - seem too small a workforce. The same sources reveal similar constellation for the Provinces of Sabaragamuwa (200 acres coffee, 26.000 acres tea, 28.000 resident labourers) and Uva (21.000 acres coffee, 18.000 acres tea, 32.000 resident labourers). Although allowances have to be made for a number of distorting factors pointed out in the following paragraph, the difference between 1881 and 1891 is striking and generally supports the notion that estate employment acted as a social security valve to the local Sinhalese in times of economic hardship.

That the figures produced by the above calculation cannot be viewed as accurate estimates of the number of labourers required on the Ceylonese plantations is self-evident. The statistical (acreage) data collected by the colonial administrators in the Blue Books-although comparatively reliable for the time and the circumstances - offers enough scope for misestimates and under-/over-enumerations. Also, the contemporary figures on labour requirements per acres remain what they are-mere estimates, approximations. Furthermore, the method of multiplying acreage and labour requirements per acre and thus arriving at the total number of workers needed is inaccurate and does not account exactly enough for crop interplanting or varying yields. But all of these problems apply to both the 1881 and the 1891 estimate and, thus, do not seriously weaken the comparative result. However, as pointed out by several colleagues, it has to be taken into account that the population census has generally been compiled during the slack season, when a part of the Tamil plantation population had

32 Report on the Census of 1891, p. 41.

33 See Wenzlhuemer, "Sinhalese Contribution to Estate Labour."

34 Report on the Census of 1891, p. 41.

35 Ceylon Statistical Blue Book 1891.

36 International Population Census Publications. Series 2. Pre-1945. Sri Lanka 1881.1 thru 1931.2. [5 Microfilms]. 
already gone back to South India only to return for the next harvesting season. As tea cultivation required year-round attendance and picking and, thus, a more permanent workforce, this practice may have distorted the calculations' results. Nevertheless, it seems absolutely unlikely that the striking difference between 1881 and 1891 labour requirements can totally be attributed to seasonal labour migration.

Thus, our little calculation supports the qualitative evidence. Around 1881 the economic pressure on the Sinhalese highland peasantry was still comparatively low. Taxes were light and payable in kind or in cash which could sometimes be obtained from the remains of peasant coffee cultivation. The pressure on land and other ecological resources had relaxed considerably with the coffee crisis. Besides, most of the chena land was situated at locations too high for successful coffee cultivation. Naturally, clashes between the planting community and the peasantry occurred over diverse issues, but altogether the Sinhalese villagers were able to make a living from their paddy and chena lands. This changed dramatically in the 1880 s. Depleted state coffers and later the expanding tea industry with its hunger for more suitable land started to make a deep impact on the peasants' living conditions. The rigorous enforcement of grain tax payment and the increasing encroachment of the planting community on chena land constitute those two developments with the most disastrous effects on the economic situation of the highlands peasantry - eventually forcing many former subsistence farmers to take up wage labour on the plantations.

\section{The ENFORCEMENT OF PADDY TAX COLLECTION}

The origins of the Paddy Tax can be traced back to the time of the Sinhalese kings. The Portuguese and the Dutch took over the tax and modified it. Under the Dutch a renting system was introduced and soon became the most widespread form of collecting the tax. ${ }^{37}$ Furthermore, the Dutch exempted the produce of garden land from the tax and field paddy practically remained the only crop subjected too the tax. The British inherited the Dutch system and added the possibility of voluntary commutation in cash in $1831 .^{38}$ However, the

${ }^{37}$ K. M. De Silva, A History of Sri Lanka (Delhi: Oxford University Press, 1981) 309; D. Wesumperuma, "Land Sales under the Paddy Tax in British Ceylon," Vidyodaya Journal of Arts, Science and Letters, 2 (1969) 19.

38 De Silva, History of Sri Lanka, 310; Wesumperuma, "Land Sales under the Paddy Tax," 19.

De Silva and Wesumperuma both date the introduction of the commutation system back to "around 1830". According to GA Fisher, the commutation system was introduced to the Kandyan highlands in the year 1831-CO 54/590, November 25th 1890/No. 465. Havelock to Knutsford. Enclosure. 
commutation system was not introduced to the whole island, as this was beyond the capacity of the British administration. But in regions such as the Kandyan highlands the commutation system was introduced and swiftly adopted by the local peasantry as "it must be borne in mind that since 1831 the commutation registers have been regarded by the Kandyan people as the strongest evidence of [land] title." 39

The engagement of large parts of the Kandyan peasantry in small-scale cash crop cultivation-namely the cultivation of native coffee-considerably facilitated the adoption of the commutation system, as cash was available to pay the Paddy Tax. Therefore, the Ordinance 5 of 1866, implemented to provide the Government with the legal machinery to seize and sell the property of tax defaulters, "remained almost a dead-letter" 40 as long as peasant coffee prospered in the highlands. With the gain from the sale of coffee, most peasants registered for commutation were able to pay the Paddy Tax. Only in rare cases, paddy cultivators defaulted in their payments, and if so, Ordinance 5 was usually not strictly enforced.

But when the treasury felt the first signs of an economic depression in the late 1870 s and early 1880 s, the relaxed attitude of the Government towards the tax defaulters changed quickly. To make up for the losses in revenue, the accumulation of arrears was not tolerated anymore. And if the defaulter was not able to pay the Paddy Tax (and the arrears, if any), Ordinance 5 of 1866 was strictly enforced. Due to the ruin of the peasants' coffee gardens, which took place several years earlier than the island-wide collapse of the coffee industry, many paddy cultivators could not pay the tax. Consequently, many defaulters were evicted from their lands and the Government sold the land to recover the tax and the arrears. As the commutation system had been widely adopted in the central highlands and the depression hit hardest here, most of those land sales took place in the Central Province and in the Province of Uva. ${ }^{41}$

In the Walapane Division of the CP and in the Udukinda Division in Uva the remorseless enforcement of Ordinance 5 and the subsequent evictions had the most dramatic consequences. In the Administration Report of the year 1886 the Assistant Government Agent of the Nuwara Eliya District, Cecil J. R. Le Mesurier, first referred to the wretched condition of the people of Walapane, ${ }^{42}$

${ }^{39}$ CO 54/590, November 25th 1890/No. 465. Havelock to Knutsford. Enclosure.

40 D. Wesumperuma, "The Evictions under the Paddy Tax, and their Impact on the Peasantry of Walapane, 1882-1885," Ceylon Journal of Historical and Social Studies 10 (1967): 132.

41 Wesumperuma, "The Evictions under the Paddy Tax," 132.

42 Wesumperuma, "The Evictions under the Paddy Tax," 132-3. 
but it took another three years until it became a public issue. In the Administration Report, Le Mesurier pointed out that between 1882 and 18852.899 paddy fields in Walapane had been sold to recover the Paddy Tax. Given a total of 18.846 fields, this amounts to $15,4 \%$ of all paddy fields. According to him, 989 fields went out of cultivation at all. As a consequence, 1.048 of the former owners had already died by 1886. 382 families had left the district. Le Mesurier stated that the population of the villages affected by the excessive land sales decreased from 34.216 in 1881 to 30.693 in $1886 .{ }^{43}$

The incidents in Walapane and Udukinda, therefore, were the natural consequence of several developments: the collapse of peasant coffee, the negative impact of plantations and forest clearings on the water supply, the constant over-assessment of paddy fields by the Government and the native headmen and, finally, the rigorous recovery of tax arrears and the strict enforcement of Ordinance 5 of 1866 to refill the empty treasury during the depression of the early 1880s. Only in 1892 - after years of constant agitation for its abolitionthe then Governor Havelock did away with the Paddy Tax as rising revenues from the flourishing plantation industry finally allowed to do so.

\section{CONFLICTS OVER CHENA LAND}

As only the richest paddy cultivators in Ceylon managed to make a decent living out of the produce of their paddy fields during the 19th century, many peasants supplemented their diet with slash-and-burn cultivation in the vicinity of the village-chena cultivation. Chenaing not only provided subsidiary food crops to the paddy cultivators, it also served as the only means of living for families that had no share in the village paddy fields. When commonly held paddy fields were split up under the Partition Ordinance or due to indebtedness, peasants frequently lost their stake in the village fields and had to rely fully on the chena crops. According to Meyer, "[c]hena was like a safety valve, which prevented a breakdown in the village socio-economic balance, and eventually allowed poor peasants to postpone the decision to migrate." 44

With the ever-rising demand for coffee land on the one hand and expanding villages on the other, the conflict over land gained momentum in the 1850s and 1860 s. At the same time, the peasants' dependence on chena cultivation as an

${ }^{43}$ CO 57/99, Administration Report 1886, Report on Nuwara Eliya District, p. 37A.

44 É. Meyer, "Paddy, Garden, Chena, Plantation. Was there a Peasant strategy in the Kandyan regions of Sri Lanka before 1840?" in Meanings of Agriculture. Essays in South Asian History and Economics, ed. P. Robb (New Delhi: Oxford University Press, 1996), 191. 
additional source of subsistence steadily increased because of the rapid expansion of the coffee estates in the higher elevations. According to Ameer $\mathrm{Ali}^{45}$ and Sakar, ${ }^{46}$ the coffee plantations seriously cut into the water supplies of the peasants' lands at lower altitudes. As a consequence, the peasants' need for chenas producing supplementary crops became more pressing. Native claims to coffee plantation lands became more frequent again, and, subsequently, the government's critical view of chena cultivation further intensified. Roberts identifies the period from the 1850 s to the 1870 s-i.e. the period of the most rapid expansion of coffee cultivation - as the time, when the government significantly increased its pressure against chena cultivation. ${ }^{47}$ In the 1860 s, the colonial government began to place tight restrictions on the issuing of chena licenses. Roberts further points out that these restrictions were rigorously enforced especially in the Wet Zone regions. ${ }^{48}$ With the coffee crisis of the late 1870 s and the first half of the 1880s the resulting tensions over chena land relaxed as the expansion of the plantations came to a halt. But after $1888 / 89$, when the prospering tea industry had led Ceylon out of the depression, land became a rare commodity again. The progressing expansion of tea cultivation re-intensified the struggle for land. With the year 1891 lands sales or grants to Europeans in the planting regions rose considerably again. Especially in Uva and Sabaragamuwa an expansion of the tea estates took place at that time. The statistics on land sales in the Blue Books indicate an increase in the acreage sold to Europeans, while the amount of land sold to natives steadily fell. ${ }^{49}$ This means that the peasantry's access to suitable chena land became more and more restricted with the expansion of tea cultivation and the government severely limited the issuing of chena permits. In a time of unprecedented dependence on the rewards of slash-and-burn cultivation, this served another blow to the economic situation of the Sinhalese villagers.

45 A. C. L. Ameer Ali, "Peasant Coffee in Ceylon during the 19th Century," Ceylon Journal of Historical and Social Studies (new series) 2 (1972): 56.

${ }^{46}$ N. G. Sakar, Demography of 20th Century Ceylon (Unpubl. PhD Thesis University of London, 1954), 390.

47 M. W. Roberts, "Land Problems and Policies, c. 1832 to c. 1900," in University of Ceylon History of Ceylon (UCHC). Vol. III: From the Beginning of the Nineteenth Century to 1948, ed. K. M. De Silva (Peradeniya: Ceylon University Press, 1973), 128.

48 Roberts, "Land Problems and Policies," 128.

49 Ceylon Statistical Blue Books, 1890-1900. 


\section{Sinhalese Estate Wage Labour as Economic Security Valve}

Taking into account the economic pressure experienced by the Sinhalese peasantry in the late 1880 s and early 1890 s it becomes clear that many villagers had to look for alternative ways to make a living, i.e. for work at the plantations. At the same time, the expanding tea estates experienced the first labour shortage for a decade. During the coffee crisis a good many of the Tamil labourers had re-migrated to their homelands in South India. Accordingly, the take-off of tea cultivation quickly produced such a high demand for labour that it could not be satisfied immediately by Tamil immigration. The cultivation of tea was more than twice as labour intensive as that of coffee and it required a steady year-round workforce, while coffee cultivation features seasonal peaks in labour demand. At that time only semi-organised labour migration between South India and Sri Lanka responded too slowly to the skyrocketing and changing demands. Therefore, the economic pull of the plantation industry attracted impoverished Sinhalese villagers to regular estate labour, thereby acting as a kind of economic security valve for the Sinhalese. As we can see from official reports, ${ }^{50}$ planters' statements ${ }^{51}$ and the statistical approximation conducted earlier, the villagers responded to the plantations' call in substantial numbers and took up wage labour - a hitherto detested occupation. Some of them even left their villages altogether and became resident on the estates. This is a strong indicator of the wretched state the Sinhalese highland peasantry was in during the closing years of the 19th century and can hardly be overestimated in its significance.

\section{SCOPE FOR FURTHER RESEARCH}

Following the line of thought that has first been convincingly advanced by Éric Meyer in his work on "Sinhalese Estate Labour in British Ceylon," the present article seeks to bring together qualitative and quantitative evidence to support the notion that a large number of Sinhalese peasants found economic refuge only in taking to estate labour during the depression of the 1880s. By bringing together findings on the social implications of the enforcement of Paddy Tax collection, conflicts over chena land and the labour demand and supply of the plantation sector, I tried to paint a comprehensive picture of economic push and pull factors at work during that time. I further tried to produce

${ }^{50}$ CO 57/101, Administration Report 1887, Royal Botanical Gardens, p. 12D.

${ }^{51}$ Lewis, Sixty-Four Years in Ceylon, 191-2. 
quantitative, statistical material supporting these prior findings. It has been pointed out above that the figures employed in the calculations on labour requirements are mere estimates and, thus, subject to various-statistical and practical-distortions. Hence, the results have to be-as I am aware that they are-viewed with a critical eye. However, the striking difference between the 1881 and 1891 figures hint at a stronger-than-supposed influx of Sinhalese peasants into the estate labour sector and demand further research in that direction. More convincing statistical evidence can only be produced from working through the local Kachcheri records of the planting districts. Accordingly, there is ample scope for further research in that respect. On the one hand, it is necessary to revise the above calculations and try to obtain more accurate data on labour demands and Sinhalese workers employed on the estates. On the other, we will have to take a closer look on the economic situation of the peasantry in up- and highland Ceylon. We will have to scrutinise paddy land sales, chena restrictions, paddy harvests, inter-district labour migration, estate payrolls and much more in order to complete the hitherto only sketched picture.

\section{BIBLIOGRAPHY}

\section{Primary Sources}

Ferguson's Ceylon Handbook and Directory, 1913-14.

International Population Census Publications. Series 2. Pre-1945. Sri Lanka 1881.1 thru 1931.2. [5 Microfilms].

Public Record Office: CO 54, Original Correspondence. Vol. CO 54/524-CO 54/668.

Public Record Office: CO 56, Ceylon Acts. Vol. CO 56/1-CO 56/15.

Public Record Office: CO 57, Sessional Papers. Vol. CO 57/80-CO 57/145.

Public Record Office: CO 59, Statistical Blue Books. 1880-1900.

Public Record Office: Administration Reports. 1880-1900.

Report on the Census of 1891.

\section{Secondary Sources}

Ameer Ali, A. C. L. "Peasant Coffee in Ceylon during the 19th Century." Ceylon Journal of Historical and Social Studies (new series) 2 (1972): 50-59.

Corea, G. The Instability of an Export Economy. Colombo: Marga Institute, 1975.

De Silva, K. M. A History of Sri Lanka. Delhi: Oxford University Press, 1981.

Heidemann, F. Kanganies in Sri Lanka and Malaysia. Tamil Recruiter-cum-Foreman as a Sociological Category in the Nineteenth and Twentieth Century. Munich: Anacon Verlag, 1992.

Lewis, F. Sixty-Four Years in Ceylon. Colombo: The Colombo Apothecaries Company, 1926. Meyer, É. "Paddy, Garden, Chena, Plantation. Was there a Peasant strategy in the Kandyan regions of Sri Lanka before 1840?" In Meanings of Agriculture. Essays in South Asian History and Economics, ed. P. Robb, pp. 182-227. New Delhi: Oxford University Press, 1996.

_. “'Enclave' Plantations, 'Hemmed-In' Villages and Dualistic Representations in 
Colonial Ceylon.” In Plantations, Peasants and Proletarians in Colonial Asia. Special Issue of Journal of Peasant Studies, Vol. 19, No. 3+4, ed. E. V. Daniel, H. Bernstein, and T. Brass, pp. 199-228. London: Cass, 1992.

- "Between Village and Plantation. Sinhalese Estate Labour in British Ceylon." In Asie du Sud Traditions et Changements. VIth European conference on Modern South Asian Studies, Sevres. 8-13 Juillet 1978. (Colloques internationaux du Centre national de la recherche scientifique), pp. 1-10. Paris: CNRS, 1978.

Peebles, P. The Plantation Tamils of Ceylon. London; New York: Leicester University Press, 2001.

Rajaratnam, S. "The Growth of Plantation Agriculture in Ceylon, 1886-1931." Ceylon Journal of Historical and Social Studies 4 (1961): 169-202.

Roberts, M. W. "Land Problems and Policies, c. 1832 to c. 1900." In University of Ceylon History of Ceylon (UCHC). Vol. III: From the Beginning of the Nineteenth Century to 1948, ed. K. M. De Silva, pp. 119-45. Peradeniya: Ceylon University Press, 1973.

—_. "Indian Estate Labour in Ceylon during the Coffee Period (1830-1880)-Part I." The Indian Economic and Social History Review 3 (1966): 101-36.

Sakar, N. G. Demography of 20th Century Ceylon. Unpubl. PhD Thesis University of London, 1954.

Snodgrass, D. R. Ceylon. An Export Economy in Transition. Homewood, Ill: Richard D. Irwin, 1966.

Webb, J. L. A. Tropical Pioneers. Human Agency and Ecological Change in the Highlands of Sri Lanka, 1800-1900. Athens: Ohio University Press, 2002.

Wenzlhuemer, R. "Reconsidering the Sinhalese Contribution to Estate Labour in late 19th Century Ceylon." Paper presented at the 17th European Conference on Modern South Asian Studies in Heidelberg, September 9-14, 2002.

Indian Immigrant Plantation Workers in Sri Lanka. A Historical Perspective 1880-1910. Kelaniya: Sri Lanka Foundation Institute, 1986.

"Land Sales under the Paddy Tax in British Ceylon." Vidyodaya Journal of Arts, Science and Letters, 2 (1969): 19-35.

"The Evictions under the Paddy Tax, and their Impact on the Peasantry of Walapane, 18821885." Ceylon Journal of Historical and Social Studies 10 (1967): 131-48.

Wickremeratne, L. A. "The Establishment of the Tea Industry in Ceylon. The First Phase, c. 1870 to c. 1900." Ceylon Journal of Historical and Social Studies (new series) 2 (1972): $131-55$. 